\title{
The Relative Ability of Earnings and Cash Flow from Operations in Predicting Future Cash Flows: Evidence from India
}

\author{
Mwila Joseph Mulenga \\ Assistant Lecturer, Institute of Finance Management (IFM), \\ Dar es Salaam, Tanzania \\ E-mail: mwilamulenga2011@gmail.com
}

DOI: 10.5296/ijafr.v5i2.8468 URL: http://dx.doi.org/10.5296/ ijafr.v5i2.8468

\begin{abstract}
The current study examines ability of earnings and cash flow from operations in predicting future cash flow from operations of Indian companies listed in Bombay stock exchange from 2002 to 2014. The study used cash flow from operations directly reported in the cash flow statement. For the purpose of estimating regression models, Ordinary least square approach used and in measuring the predictive power of each models in forecasting future cash flow adjusted $R$-squared used as forecasting measure. The findings of this study reported cash flow from operations to have more power in than earnings in predicting future cash flow, which do not support the assertion given out by Financial Accounting Standards Board. The findings of this study provide additional insights to Indian capital market researchers and also benefit users of accounting information in India by providing them with empirical evidence on the beneficial ability of cash flow data in predicting future cash flow and that would assist them in making their investment decisions, lending and other decisions and also knowing the financial status of company they wish to invest.
\end{abstract}

Keywords: Cash flow from operations, Earnings, Future cash flow from operations, Prediction.

\section{Introduction}

Research on the relative ability of earnings and cash flow data to predict future cash flow and earnings is the line of research examined under capital market based accounting research (Beisland,2011) and another line of research that is also investigated under capital market based accounting research (CMBAR) is called value relevance research, which used accounting information and measuring its ability in capturing stock prices or stock returns (Vijitha and Nimalathan,2014).A study of Kim and Kross (2005), Tharmir,A.B. (2011) and Beisland (2011) were among of the few studies examine value relevance of accounting information and their ability in predicting future cash flow and earnings. 
The study on the relative ability of accounting information in predicting future cash flow based on the assertion given out by FASB (1978) and IASB (1989) which asserts that apart from cash flow it is earnings and its components have a better predictive power of future cash flow than cash flow from operations. Theoretically, the reason for such assertion possibly may lie in the argument that earnings mitigates problems of matching and timing that is inherited in cash flow from operations through accruals and based on the different choices of accounting policy, arbitrary allocations of a product and nature of accruals may lead managers to do manipulation in accruals (Farshadfar, Chew $\mathrm{Ng}$ and Brimble ,2008). The results may lead earnings data to have less predictive power in forecasting future cash flow than cash flow measure (Dechow ,1994).

This study aimed in examine the ability of earnings and cash flow from operations in predicting future cash flow from operations, following Farshadfar et al. (2008) and Ahmadi and Ahmadi,V.(2012). The future cash flow used as the predictive measure for the reason that play a vital role and considered as useful and significant to the different users of accounting information including investors, creditors, analysts and others in investing, lending and other decision making (Bowen et al., 1986).Also the measure of future cash flow accord with the main objective of financial reporting as stated out by accounting standards setters which aimed in assisting users especially stock investors in predicting inflow and outflow of cash and also estimating the value of the company (Holthausen \& Watts, 2001).

Indian Accounting standards (IAS 3) which deals with cash flow statements, pointed out, the uses accounting information from the cash flow statement together with other accounting information assist users in evaluating the ability of the companies in generating future cash flow.Also (FASB 1978,para 37) pointed out the main aim of financial reports under Statement of Financial Accounting concepts is to assist users of accounting information in evaluating amounts, timing and uncertainty of future inflow and outflow of cash (Farshadfar, Chew Ng and Brimble, 2008).

In line with the above view, the requirement for the disclosure of statement of cash flow needed by the accounting standard setters as the basic component of financial reporting of the particular company across the world (Farshadfar, Chew Ng and Brimble (2008).Based on India context the requirement for the disclosure of cash flow statement became mandatory to listed companies since the financial year ended 2001-2002 and that accelerate the interest of different researchers to use information from the cash flow

statement for their study because information presented in cash flow statement found to be the most important and useful accounting information used by different users in evaluating financial performance of the companies (Sharma.et al,2012). For example previous work of Srinivasan, P and Narasimhan, M.S. (2005), Vishnani and Shah (2008) and Sharma, Kumar and Singh (2012) in India used accounting information from cash flow statement for the purpose of examine its relevant for equity valuation in Indian stock market. This study focused on examines ability of cash flow from operation and earnings data to predict future cash flow of listed Indian companies. There is limited number of empirical studies providing evidence related to the ability of earnings and cash flow from operation in forecasting future 
cash flow in India since the requirement for the disclosure of cash flow statement became mandatory to Indian listed companies.

This study aims to meet the following research objectives:

1. Examine ability of earning and cash flow from operations data in forecasting future cash flow for Indian companies listed in BSE under BSE SENSEX.

2. Identify the model which is having a greater predictive power in forecasting future cash flow for Indian companies listed in BSE under BSE SENSEX.

To meet above research objectives, four hypotheses formulated and then tested using two forecasting models with one-year, two-year and three year lagged each, recently used in the study of Efayena, O (2015) and ordinary least squares approaches employed as estimation method.

The rest of the paper structured as follows. Section 2 presents the review of literature related to the ability of earnings and cash flow in forecasting future cash flow followed by methodology in section 3 where information related to data, sample selection, definition of variables used in the study and model specification discussed and next section is where presentation of the empirical results shown in section 4 . While section 5 is where the summary and conclusion of the study discussed.

\section{Review of literature}

The review of literature section cover the definition of important concepts used in the study, where the importance of cash flow prediction explained and the summary of the previous and recent empirical work related to the relative ability of cash flow from operation and earnings data in forecasting future cash flows presented.

\subsection{Definition of concepts}

Definition of key concepts used in this study, including cash flow, earnings and how does it measured and used in various studies by different researchers discussed under this section.

\subsubsection{Meaning of cash flow}

Cash flow information considered as the part of accounting information published and presented in the cash flow statement of a particular company (Farshadfar, Chew $\mathrm{Ng}$ and Brimble, 2008) and also Zwaig \& Pickett (2001) considered cash flow as significant financial indicator of financial problem where any decline in the amount of company cash flow will provide early signal warning of bankruptcy to the users like creditors and others.

The use of this information assists different users of accounting information including investors and others in serving their different purposes. Example investors or security analysts need such information for the purpose of valuing their investment in the capital markets (Chotkunakitti, 2005), managers need such information for the purpose of identifying financial problem that will face the company in the near future (Kelly \& O'Connor 1997) while management need such information for the purpose of knowing the available amount of cash in the company (Schaeffer 2002).

In respect of cash flow data used in the previous studies, the study of Chotkunakiti, (2005), Jemaa et al (2015) and Farshadfar, Chew Ng and Brimble (2008) used information related to 
cash flow from operations directly extracted from the cash flow statement while the study of Beisland (2011), Biddle et al. (1995) and Finger (1994); Klein \& Marquardt (2006) used cash flow by considering the difference between net income before extraordinary items minus accruals. On the other hand Bowen, Burgstahler and Daley (1986) obtained cash flow from operation by doing adjustment of cash flow from changes in net working capital, cash flow investment, and cash flow from financing activities.

\subsubsection{Earnings}

Earnings also used as the driver of the value of the company (Beisland, 2011).In accounting, earnings occupy a key position and considered as an important measure which show the summary of accounting that assisting in measuring performance of the firm in debt contracts and management (Dechow, Kothari and Watts, 1997) and valuation of company's share (Push Bhatt and Sumangala, K., and Dechow, Kothari and Watts, 1997).

Regarding the uses of earnings in predicting future cash flows, the study of Farshadfar, Chew $\mathrm{Ng}$ and Brimble (2008) and Beisland (2011) used earnings after tax but before extraordinary items, and other researchers like Jemaa el al (2015) used net income and operating income as the proxy of earnings in their study. Operating earnings also use as the proxy of earnings in the study of Ahmadi, A and Ahmadi, V. (2012) and Bagheri, Pouraghajan and Emmgholipour (2012).

\subsection{Importance of cash flow prediction}

Prediction of cash flow considered as significant task needed in various economic decisions that assists users of accounting information especially investors to use future cash flow information for the investment purpose (Chotkunakiti,2005), investors need such information in valuing their investment by considering the value of their investment in the company as the present value of the future cash flow. The task of predicting company future cash flow also assist investors to know the ability of the company in paying dividends in the near future period (Neill et al. 1991, Lee, 1993 and Lawson, 1992). Neill et al. (1991), Lee, (1993) and Lawson, (1992) pointed out for the best provision of relevant information related to the investment decisions, there should be a comparison between cash flow prediction and actual cash flow. The prediction of future cash flow by using accounting information such as cash flow from operations, earnings and accruals assist different users of accounting information to meet their needs particularly investors, managers, analysts in decisions like investment and lending (Bowen et al ,1986 and Neil et al,1991).

\subsection{Empirical findings related to the relative ability of earnings and cash flow from operations in predicting future cash flows.}

The seminar work of Greenberg, Johnson, and Ramesh (1986), Bowen, Burstahler and Daley (1986) and Brooks (1981) considered as the previous work investigated the ability of earnings and cash flow data in forecasting future cash flow. Greenberg, Johnson, and Ramesh's study used adjusted R-squared in determine ability of earnings model and cash flow model in predicting future cash flow by using a sample 157 industries companies selected from COMPUSTAT database from 1963-1982.They reported earnings to have strong 
power in predicting future cash flows through earnings model than current and past cash flows. While Bowen, Burstahler and Daley (1986) used earnings, cash flow from operations and other traditional measures of cash flow including from working capital from operations, net income plus depreciation and amortisation, cash flow after investment, change in cash and as independent variables in predicting future cash flow. They found different results compared to the work of Greenberg, Johnson, and Ramesh (1986). They reported earnings to have a weak power in predicting future cash flow while traditional measures of cash flows including working capital from operations and net income plus depreciation and amortization found to have greater power predicting future cash flows.

The results of Greenberg, Johnson, and Ramesh (1986) found to be consistent compared to the work of Dechow, Kothari and Watts (1998), where they developed theoretical framework and reported earnings as the best predictor of future cash flow of 1337 firms from the period of 1963 to 1992 and inconsistent with the previous work of Brooks (1981) where it was cash flow from operations reported to have a better predictive power of future cash flow by using a sample of thirty companies selected from COMPUSTAT database. Brook's results also provide empirical evidence directly against assertion given out by the FASB in 1978 .

Several studies investigated ability of earnings and cash flow from operation in forecasting future cash flow separate with the value relevance studies, example the study of Ahmadi, A. and Ahmadi,V. (2012), Telmoudi and Noubbigh (2010) and Jemaa et al (2015). But the study of Beisland, L (2011), Tharmir,A.B.(2011) and Kim and Kross (2005) were among of the few researchers examine the value relevance of accounting information and their ability in predicting future cash flow and earnings.

Based on the predictive ability of accounting information Beisland (2011) used earnings and cash flow and measuring its ability in predicting future cash flow and earnings by using a sample of Norwegian companies listed in Oslo Stock Exchange from 1992 to 2004 and reported accounting information are more relevant in investigating their ability in predicting future earnings than future cash flow. In addition, Kim and Kross (2005) investigated the ability of current earnings in forecasting future cash flow and reported the power of earnings in forecasting future cash flow has been increased.

The results of Beisland, L. (2011) and Kim and Kross (2005) found to be inconsistent compared to the recent study done by Jemaa et al (2015), Efayena,O (2015) and previous work of Farshadfar, Chew Ng and Brimble (2008) and Ahmadi, A., Bashirimanesh, and Ahmadi, V. (2013). The recent study of Efayena, (2015) reported cash flow from operation to have the most predictive power of future cash flow than earnings, similarly, Farshadfar, Chew $\mathrm{Ng}$ and Brimble (2008) found cash flow from operation has more power in predicting future cash flow of 323 companies which comprises of small, medium and large firms listed in Australian stock exchange between 1992 and 2004.Their results found to be similar with previous study of, Al-Attar and Hussain (2004), Finger (1994) and Ahsan (2010).

Currently, Jemaa et al (2015) examined ability of earnings and cash flow from operations in predicting future cash flows by using a sample 37 companies listed in Tunisian stock financial market over the period of 1998-2012.The results of their study provided empirical evidence that cash flow from operations has a greater power in predicting future cash flows 
in simple models with one or two years of delay. However, earnings reported to have more power than cash flow from operations in predicting future cash flows in multi-year models.

The same variables used in this study as the predictors of future cash flows previously used in the work of Ahmadi and Ahmadi (2012) for the purpose of examine its ability in forecasting future cash flow of 95 firms listed in Tehran stock exchange. Two regression models developed for the purpose of examine the relationship between variables, where Mean absolute percentage error (MAPE) used as forecasting measure. The study reported the same results previously reported in the study of Al-Attar and Hussain (2004), Ahsan (2010), Farshadfar, Chew Ng and Brimble (2008) and the recent study of Jemaa et al (2015).

In addition the study of Chotkunakitti (2005) investigated the ability of cash flow data directly sourced from the cash flow statement, accruals and earnings in forecasting future cash flow of non- financial firms listed in the stock exchange of Thailand. The empirical findings of Chotkunakitti reported all accounting information used in the study can be used in forecasting future cash flow but the variable that is reported to have the better predictive power than others is cash flow from operations. The results found to be inconsistent compared to the work of Tharmir, A.B.(2011) and matched with Al-Debi'e (2011) and the recent work of Efayena, O (2015).

Tharmir, A.B. (2011) also investigate the ability of cash flow data, earnings and accruals in forecasting future cash flow of firms listed in Saudi stock market by using theoretical framework of Barth, Cram and Nelson (2001) and Dechow, Kothari and Watts (1998).The empirical results reported earnings and accruals were able in predicting future cash flow.Tharmila's results found to be inconsistent with the previous work of Mc Beth (1993) Penham and Yehuda (2009), Lev et al. (2010).

The previous work of Lev, Li, and Sougiannis (2005), Sloan (1996), Barth, Cram and Nelson (2001), Dechow et al (1998), Al-Attar and Hussain (2004) and Lorek and Willinger (1996) also used accruals components of earnings and cash flow from operations and examine its ability to predict future cash flows. But their results found to be inconsistent among themselves, example Al-Attar and Hussain (2004) and Barth, Cram and Nelson (2001) found the disaggregation of earning into cash flows and accruals to have a better predictive power of future cash flows, the results found to be inconsistent compared to the previous study of Lev, Li, and Sougiannis (2005).

From the review of literature, most of the previous work focused on measuring ability of earnings, cash flow from operations and accruals in forecasting future cash flow were coming from the developed countries, example the study of Bowen et al. (1986); Finger (1994); Farshadfar et al. (2008); Al-Attar and Hussain (2004); Penham and Yehuda (2009); Lev et al.(2010); Waldron and Jordan (2010) and Arnedo et al. (2012) and only few studies were coming from developing countries, example the study of Chotkunakitti (2005), Efayena,O. (2015), Supriyadi (1998), Telmoudi and Noubbigh (2010) and Al-Debi'e (2011). Their results found to be inconclusive among themselves. India is among of developing country where there is a number of few studies used cash flow from operations and earnings data for the purpose of examine its ability to predict future cash flows. Therefore this study aimed to fill the gap in literature and investigate whether it is earnings or cash flow from 
operations has greater power to predict future cash flow for Indian companies, by using two regression models and find out whether the results of this study matched with the assertion given out by FASB (1978) and IASB (1989).

\subsubsection{Hypotheses}

The following hypotheses proposed based on the research problem to meet the above research objectives.

Ho: The relative predictive ability of past earnings in forecasting future cash flows for Indian companies is higher than the ability of past cash flows from operation.

Ho: Forecasting model with earnings as a predictor of future cash flow have a greater power in predicting future cash flow than forecasting models with cash flow from operation as a predictor of future cash flow.

Ho: Forecasting cash flow models including two or more previous year data has a greater power in predicting future cash flow than forecasting cash models with only one previous year data.

Ho: Forecasting earnings models including two or more previous year data has a greater power in predicting future cash flow than forecasting earnings models with only one previous year data.

\section{Methodology}

\subsection{Data and methodology}

The study used secondary data extracted from the annual financial reports of companies used in the study. The accounting information used including cash flows from operations and earnings, both collected directly from the cash flow statement and income statement of the companies listed in BSE under BSE SENSEX respectively. The data were collected from the Prowess data base of CMIE (Centre for Monitoring Indian Economy.).

In estimating regression models Ordinary Least Square method employed and adjusted R-squared value of regressions models used as forecasting measure for the purpose of evaluating ability of the models used in the study. According to Hair et al (1998) as cited from Mooi, T.L. (2007) if the value of adjusted R-squared is higher it means there would be greater explanatory power of the regression equation and provide a better prediction of dependent variable.

For the purpose of achieving the first objective of this research, beta coefficients of the predictors of future cash flow examined. According to Mooi, T.L. (2007) beta coefficient represents standardized coefficient that allows direct link between coefficients and its relative explanatory power of dependent variable and a variable with a significant coefficient meaning that there is an increase in the explanatory power of the regression equation (Hair et al., 1998) as cited from Mooi, T.L. (2007)

\subsection{Sample selection}

Our sample comprises of 26 companies, all from BSE SENSEX. Out of 30 companies listed 
under BSE SENSEX, only 26 companies included in the sample due to the availability of data.BSE SENSEX selected as a proxy of Indian stock market because represents approximately $50 \%$ of the total market capitalization of Indian stock market and a year for the purpose of sample classification starts from 2001-2002 to 2013-2014.

\subsection{Definition of accounting variables used in the study}

The study used earnings and cash flows from operations as predictor variables, both were sourced directly from the annual financial reports composed of the cash flow statement and income statement respectively and the variables used defined as follows.

\subsubsection{Cash flow from operations}

Cash flow from operations defined as inflow and outflow of cash from operating activities as reported in the cash flow statement of a particular company (Jemaa et al, 2015). The same definition of cash flow from operations given out by Farshadfar, Chew $\mathrm{Ng}$ and Brimble (2008).While other studies of Beisland (2011), Biddle et al. (1995) and Finger (1994), Klein \& Marquardt (2006) and Rayburn, (1986) defined the term cash flow as the different between net income before extraordinary items minus accruals. For the purpose of this study, cash flow from operations defined the same way as it was define by Jemaa et al (2015) and Farshadfar, Chew Ng and Brimble (2008).

\subsubsection{Earnings}

This study used earnings after tax before extraordinary items as a proxy for earnings, following Farshadfar, Chew $\mathrm{Ng}$ and Brimble (2008) and Takhtaei, N and Karimi, H. (2013). While, other researcher like Jemaa el al (2015) used net income and operating income as the proxy for earnings in their study. The variables used in the study scaled by using average total assets (sum of previous year total assets plus current year total assets divided by

2) following Barth et al (2001), Quirin et. al. (1999); Farshadfar, Chew Ng and Brimble (2008) and Efayena, O. (2015)

\subsection{Model specification}

The study used the following regression models which include three year horizon (1 year lag,2 year lag and 3 year lagged) recently analyzed by Efayena, O. (2015).

3.4.1. Prediction models with cash flow from operation as a predictor of future cash flow

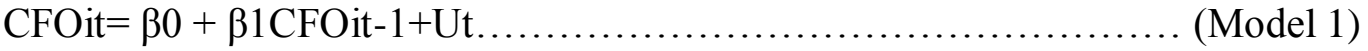

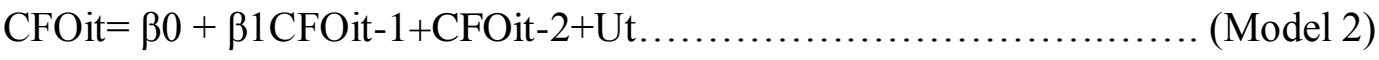

$$
\begin{aligned}
& \mathrm{CFOit}=\beta 0+\beta 1 \mathrm{CFOit}-1+\mathrm{CFOit}-2+\mathrm{CFOit}-3+\mathrm{Uit} \ldots \ldots \ldots \ldots \ldots \ldots \ldots . \ldots(\text { Model } 3)
\end{aligned}
$$

Where $\mathrm{i}$ stand for firm and $\mathrm{t}$ as year; $\mathrm{CFO}=$ Future cash flow from operations (used as dependent variable) regressed upon its past values, scaled by average total assets;CFOit-1,CFOit-2,CFOit-3= Cash flow from operations for year t-1,t-2 and t-3 lagged (independent variable) and $\beta 0, \beta 1, \beta 2$, and $\beta 3$ are regression coefficient and $U$ used as error term.

3.4.2. Prediction models with earnings as a predictor of future cash flow from operations.

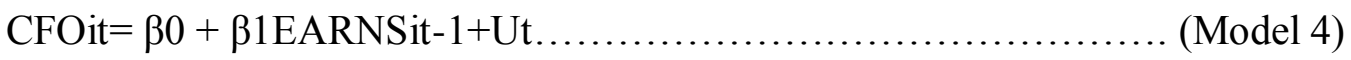

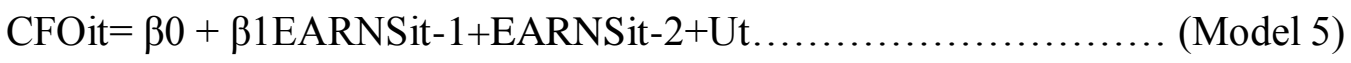


$\mathrm{CFOit}=\beta 0+\beta 1 \mathrm{EARNSit}-1+\mathrm{EARNSit}-2+\mathrm{EARNSit}-3$

(Model 6)

Where: EARNSit-1, EARNSit-2, EARNSit-3=Earnings after tax before extraordinary items (independent variable) also scaled by average total assets for year $\mathrm{t}-1, \mathrm{t}-2$ and $\mathrm{t}-3$ lagged.

\section{Empirical results}

Table 1. Descriptive statistics

\begin{tabular}{|l|l|l|l|l|l|}
\hline & Mean & Median & Std.Deviation & Maximum & Minimum \\
\hline CFOit & 0.1545 & 0.1288 & 0.1297 & 0.6835 & -0.1105 \\
\hline CFOit-1 & 0.1647 & 0.1346 & 0.1392 & 0.9130 & -0.1105 \\
\hline CFOit-2 & 0.1695 & 0.1357 & 0.1388 & 0.9130 & -0.1105 \\
\hline CFOit-3 & 0.1759 & 0.1357 & 0.1399 & 0.9130 & -0.0635 \\
\hline EARNS & 0.1074 & 0.0864 & 0.0965 & 0.5235 & -0.1213 \\
\hline EARNSit-1 & 0.1102 & 0.0918 & 0.0973 & 0.5235 & -0.1213 \\
\hline EARNSit-2 & 0.1112 & 0.0909 & 0.0984 & 0.5235 & -0.1213 \\
\hline EARNSit-3 & 0.1116 & 0.0864 & 0.1028 & 0.5235 & -0.1213 \\
\hline
\end{tabular}

Notes: The table above report the descriptive statistics of variables, where: CFO represents future cash flow from operations and used as dependent variable and CFOit-1,t-2 and t-3 named as past cash flow from operations at one year lagged, two year and three year lagged. On the other hand EARRNSit-1, t-2 and t-3 used as past earnings at one year, two and three lagged.

Table 1 presents descriptive statistics for the dependent and explanatory variables used in the study and the results show EARNS has a mean value of 0.1074 and median value of 0.0864 meanings that on average, $0.1074(10.74 \%)$ firms' assets earn positive income. On the other hand CFO also reported to have the mean value of 0.1545 and median value of 0.1288 , meaning that on average, 0.1545 (15.45\%) firms listed in BSE under BSE SENSEX have positive cash flow. The results of mean value of EARNS and CFO showed a positive value. These results found to be consistent with the recent work of Jemaa, O.B., Toukabri, M., and Jilani, F. (2015), Jemaa et al (2015) and Efayena, O. (2015) and inconsistent with the previous work of Farshadfar, Chew $\mathrm{Ng}$ and Brimble (2008) where it is only cash flow from operations reported to have positive mean value while earnings found to have negative mean value. To sum up, the value of mean and median value of CFO found to be greater than the mean value and median value of EARNS. This implies that EARNS has a positive influence on CFO, wherever there is an increase in EARNS there would be an increase in CFO too. 
Table 2. Co linearity Statistics

\begin{tabular}{|l|l|l|}
\hline Variables & Tolerance test & VIF \\
\hline CFOit-1 & 0.347 & 2.881 \\
\hline CFOit-2 & 0.349 & 2.865 \\
\hline CFOit-3 & 0.356 & 2.809 \\
\hline EARNSit-1 & 0.183 & 5.464 \\
\hline EARNSit-2 & 0.119 & 8.403 \\
\hline EARNSit-3 & 0.199 & 5.025 \\
\hline
\end{tabular}

Table 3. Pearson Correlations Coefficient of Variables

\begin{tabular}{|l|l|l|l|l|l|l|l|l|}
\hline & CFO & CFOit-1 & CFOit-2 & CFOit-3 & EARNS & EARNSit-1 & EARNSit-2 & EARNSit-3 \\
\hline CFO & 1 & & & & & & & \\
\hline CFOit-1 & 0.732 & 1 & & & & & & \\
\hline CFOit-2 & 0.690 & 0.669 & 1 & & & & & \\
\hline CFOit-3 & 0.579 & 0.623 & 0.663 & 1 & & & & \\
\hline EARNS & 0.840 & 0.715 & 0.663 & 0.608 & 1 & & & \\
\hline EARNSit-1 & 0.751 & 0.773 & 0.708 & 0.648 & 0.872 & 1 & & \\
\hline EARNSit-2 & 0.670 & 0.667 & 0.765 & 0.700 & 0.751 & 0.864 & 1 & \\
\hline EARNSit-3 & 0.555 & 0.570 & 0.652 & 0.754 & 0.679 & 0.734 & 0.866 & 1 \\
\hline
\end{tabular}

The tables above show the correlation between the variables used in study and the results of colinearity statistics. Most of the coefficients are found to be significant and the highest correlation coefficient among independent variables is 0.827 while the lowest is 0.570 .As explained by Lind et al (2008) there would be no problem using both independent variables if the correlation coefficient exist between variables is between -0.7 and -0.7 .The study reported highest correlation between independent variable is 0.866 But all independent variables used in the regression models have been checked for multicollinearity using the Variance inflation factor (VIF) and Tolerance test and the results reveals no sign of multicollinearity between independent variables used in the study. As suggested by Gujarati (2004) and Neter, Wasserman and Kutner, (1985) as cited from Mooi, T.L. (2007) a VIF greater than 10 and tolerance test value below 0.10 is taken as a sign of multicollinearity problems. From the results given in table 2 below showing that VIF statistics ranging between 2.809 to 8.403 and tolerance test ranging between 0.119 and 0.356 and none of them have VIF more than 10 and also tolerance test below 0.10 , therefore there is no sign of multicollinearity problem. 
Table 4.Ordinary least squares regression results of future cash flow from operations on cash flow from operations.

Dependent variable: Future Cash flow from operations

\begin{tabular}{|l|l|l|l|l|l|l|}
\hline & \multicolumn{3}{l}{ Model 1 } & \multicolumn{2}{l|}{ Model 2 } & Model 3 \\
\hline & Coef & t-value & Coef & t-value & Coef & t-value \\
\hline Constant & 0.048 & 5.613 & 0.030 & 3.211 & 0.019 & 2.203 \\
\hline CFOit-1 & 0.674 & $16.774^{* *}$ & 0.460 & $8.268^{* *}$ & 0.436 & $8.445^{* *}$ \\
\hline CFOit-2 & - & - & 0.325 & $5.972^{* *}$ & 0.311 & $5.743^{* *}$ \\
\hline CFOit-3 & - & - & - & - & 0.062 & 1.212 \\
\hline Adjusted R & $47.4 \%$ & $52.4 \%$ & $60.6 \%$ & \\
\hline F-statistic & 281.378 & 157.531 & 133.809 & \\
\hline Prob.(F-statistic & 0.000 & 0.000 & 0.000 & \\
\hline Observations & 312 & 286 & 260 & \\
\hline
\end{tabular}

Table 4 reports the summary statistics of the OLS regression model with cash flow from operations as the predictor of future cash flow. The results indicate that, coefficient on CFO at 1 year lag and two year lag and intercepts are positive, and found to be statistically significant at 0.01 levels across three models, meaning that the variable found to have significant ability in predicting future cash flow. The results of $t$-statistic prove the significant of CFO on one year lagged. The results of this study matched with the previous work of Farshadfar, Chew $\mathrm{Ng}$ and Brimble (2008) in Australia and the recent work of Efayena, O. (2015) in Nigeria .They reported the coefficient on CFO on one year lagged to have positive and significant influence on predicting future cash flow. The results of this study also found the coefficient on $\mathrm{CFO}$ on three year lagged to have positive and insignificant influence in predicting future cash flow.

The adjusted R-squared of model 3 is 60.6 per cent, which is higher than those of Model 1 and 2 (47.4 percent and 52.35 per cent, respectively).Meaning that cash flow model of one year lag, two year lag, and three year lags explains 47.4 percent, 52.35 percent and 60.60 percent respectively of the variations of future cash flow from operations and remaining percent in each models has been explained by other factors other than cash flow from operations. To sum up the results, forecasting cash flow models which including two or more previous year data found to have greater power in predicting future cash flow than forecasting cash flow model with only one previous year data and it is forecasting model 3 found to have a greater power in forecasting future cash flow followed by forecasting model 2. 
Table 5. Ordinary least squares regression results of future cash flow from operations on earnings

\begin{tabular}{|c|c|c|c|c|c|c|}
\hline \multicolumn{7}{|c|}{ Dependent variable: Future Cash flow from operations } \\
\hline & \multicolumn{2}{|c|}{ Model 4} & \multicolumn{2}{|c|}{ Model 5} & \multicolumn{2}{|c|}{ Model 6} \\
\hline & Coef & t-value & Coef & t-value & Coef & t-value \\
\hline Constant & 0.064 & 7.763 & 0.059 & 6.457 & 0.043 & 5.229 \\
\hline EARNSit-1 & 0.900 & $15.928 * *$ & 0.950 & $7.623 * *$ & 0.904 & $8.273 * *$ \\
\hline EARNSit-2 & - & - & -0.003 & -0.028 & 0.174 & 1.186 \\
\hline EARNSit-3 & - & - & - & - & -0.071 & -0.686 \\
\hline Adjusted $\mathrm{R}^{2}$ & \multicolumn{2}{|l|}{$44.8 \%$} & \multicolumn{2}{|l|}{$45.2 \%$} & \multicolumn{2}{|l|}{$56.1 \%$} \\
\hline F-statistic & \multicolumn{2}{|c|}{253.701} & \multicolumn{2}{|c|}{118.558} & \multicolumn{2}{|c|}{111.479} \\
\hline $\begin{array}{l}\text { Prob.(F-statis } \\
\text { tic }\end{array}$ & \multicolumn{2}{|l|}{0.000} & \multicolumn{2}{|l|}{0.000} & \multicolumn{2}{|l|}{0.000} \\
\hline Observations & \multicolumn{2}{|l|}{312} & \multicolumn{2}{|l|}{286} & \multicolumn{2}{|l|}{260} \\
\hline
\end{tabular}

The summary statistics of the OLS regression model with earnings after tax as the predictor of future cash flow presented in table 5. The results indicate that the only coefficient on EARNS on one year lagged and intercepts found to be positive and statistically significant at 0.01 levels across three models. The results found to differ compared to the recent work of Efayena, O.(2015) where coefficient on EARNS at 1 year lag reported to have positive and significant influence on predicting future cash flow in one year lagged model and three year lagged model. The coefficient on EARNS on one

year lagged also reported to have positive and significant influence in predicting future cash flow for Australians companies in the previous work of Farshadfar, Chew $\mathrm{Ng}$ and Brimble (2008) and also in the recent work of Jemaa, O., Toukabri, M., and Jilani, F. (2015) in Tunisia and Efayena, O. (2015) in Nigeria.

The study also found coefficient on EARNS on two year lagged to have negative and insignificant influence on the prediction of future cash flow in model 5 while in model 6 found to be positive but also insignificant in predicting future cash flow. The results of t-statistic of coefficient on EARNS on two year lagged in model 5 and 6 prove it's insignificant in predicting future cash flow. On the other hand the coefficient on EARNS on three year lagged found to have negative and insignificant influence in predicting future cash flow. While Efayena, O. (2015) found positive and insignificant influence of the coefficient on EARNS on three year lagged in predicting future cash flow.

The value of adjusted R-squared of model 6 is 56.1 per cent, which is higher than those of Model 4 and 5 (44.8 percent and 45.2 per cent, respectively).Meaning that each model including model of one year lagged, two year lagged, and three year lagged explains about 44.8 percent, 45.2 percent and 56.1 percent respectively of the variations of future cash flow from operations and remaining percent in each models has been explained by other factors 
other than earnings. To sum up the results, forecasting earnings models including two or more previous year data has a greater power in predicting future cash flow than forecasting earnings models with only one previous year data and it is model 6 found to have a greater predictive power in forecasting future cash flow followed by model 5.

\section{Discussion and conclusion}

The overall findings of this study reported cash flow from operation provide a better predictive power of future cash flow from operations than earnings this is due to the fact that the results of coefficient on cash flow from operations at one year lagged and two year lagged and intercepts are positive, and found to be statistically significant at $1 \%$ level across three models while earnings reported to have less power in predicting future cash flow because only coefficient on earnings at one year lagged reported to have positive and significant influence on predicting future cash flow in model 4,5 and 6 while other coefficients on earnings at two year lagged and three year lagged reported to have negative and insignificant influence on predicting future cash flow, we fail to accept null hypothesis stated that the relative predictive ability of past earnings in forecasting future cash flows for Indian is higher than the ability of past cash flows from operations.

Furthermore, the results found forecasting models with cash flow operations as a predictor of future cash flow have a greater power in predicting future cash flow than forecasting models with earnings as a predictor of future cash flow, this is due to the fact that the adjusted value of R-squared obtained in forecasting models with cash flow from operation as a predictor of future cash flow reported to large compared to the value reported in the forecasting models with earnings as the predictor of future cash flow, also we failed to accept hypothesis stated that forecasting models with earnings as a predictor of future cash flow have a greater power in predicting future cash flow than forecasting models with cash flow from operation as a predictor of future cash flow.

Also the study found adjusted value of R-squared for forecasting models with cash flow from operations which including two or more previous year data is higher than forecasting cash flow model with only one previous year data, the same results reported in the forecasting models with earnings which including two or more previous year data, we failed to reject null hypothesis stated forecasting cash flow models including two or more previous year data has a greater power in predicting future cash flow than forecasting cash models with only one previous year data and another null hypothesis stated that forecasting earnings models including two or more previous year data has a greater power in predicting future cash flow than forecasting earnings models with only one previous year data. Therefore the findings of this study suggested cash flow from operations is a good predictor of future cash flow than earnings, The findings is inconsistent with the assertion given out by FASB in 1978 and IASB in 1989, which asserts that earnings has a greater power in predicting future cash flows than cash flow from operations. The findings of this study also found to be inconsistent compared to the previous work of and the study of Takhtaei,N and Karimi,H.(2013), Greenberg, Johnson and Ramesh (1999), Dechow et al (1998), Mc Beth (1993). On the other hand the results of this study matched with the work of Mooi,T.L.(2007),Lorek and Willinger 
(2009), Ahmadi, A., and Ahmadi, V. (2012), Waldron and Jordan (2010) and Arnedo et al. (2012), Finger (1994); Farshadfar et al. (2008);Lev et al. (2010); Chotkunakitti (2005) and Al-Debi'e (2011).

The results of this study should be considered in light of several limitations. The conclusions based on the analysis of only 26 companies listed in BSE under BSE SENSEX and period covered for the study is 13 years from 2002 to 2014, for better generalization of results a sample size can be increased by considering other companies listed at Bombay stock exchange and period covered can be extended. Also more empirical evidence is needed for other cash flow measures like working capital from operations and earnings after tax plus depreciation and amortization

This study used only earnings and cash flow from operations and left other cash flow measures like cash flow from investment, cash flow from financing, working capital from operations and earnings after tax before extraordinary items plus depreciation and amortization (EDPR) and operating cycle elements like timely debt collection, timely debt payment and timely flow of stock. Future research should consider other cash flow measures like in the study of Farshadfar, Chew Ng and Brimble (2008), Takhtaei, N., and Karim,H. (2013) and Mooi, T.L. (2007), Shubita, M.S. (2013), Quirin et al (1999), Subatnieks,K.(2014) and operating cycle elements like in the study of Telmoudi and Noubbigh (2010). Also the main focus of this study based on examines ability of earnings and cash flow from operations to predict future cash flow from operations only for Indian companies. Other researchers may carry out the study by considering the ability of accounting information used in this study and predicting both future cash flow from operations and future earnings, like in the study of Janatrostam (1999), Subatnieks, K. (2014), Lev, Li, and Sougiannis (2005) Wardhani, K and Almilia, S. (2013) and Orpurt and Zang (2009).

\section{References}

Ahsan, Habib (2010), "Prediction of Operating Cash Flows: Further Evidence from Australia. Australian Accounting Review.20 (2), 134-143.

Ahmadi, A., \& Ahmadi, V. (2012). Evaluating the ability of operating cash flow predictive indexes. Interdisciplinary Journal of Contemporary Research in Business,4(7).

Al-Attar, A., \& Hussain, S. (2004). Corporate data and future cash flow. Journal of Business Finance and Accounting, 31(78): 861-903.

Al-Debi'e, M. M. (2011). Are operating cash flows a superior predictor of future operating cash flows than earnings: Evidence from Jordan. European Journal of Economics, Finance and Administrative Sciences, (40), 30-46.

Arnedo, L., Lizarraga, F., \& Sanchez, S. (2012). The role of accounting accruals for the prediction of future cash flows: evidence from Spain.3, 499-520.

Barth, M.E., Cram, D.P. and Nelson, K.K. (2001).Accruals and the prediction of future cash flows.The Accounting Review, 76(1), 27-58.

Bagheri, Pouraghajan, Emmgholipour, M., Mansourinia, E., \& Adrang, F (2012). The 
evaluation of accounting earnings components ability in predicting future operating cash flows: Evidence from the Tehran Stock Exchange, Journal of Basic and Applied Scientific Research, 2(12).

Biddle, G. C., Seow, G. S., \& Siegel, A. F. (1995)_Relative versus Incremental Information Content', Contemporary Accounting Research, 12 (1), 1-23.

Bowen, R. M., Burgstahler, D., \& Daley, L.A. (1986). Evidence on the relationships between earnings and various measures of cash flow. The Accounting Review, 61(4), 713 - 725.

Brooks, J. E. (1981). An Empirical investigation of the usefulness of earnings in predicting future enterprise cash flows. Working Paper, Michigan State University

Chotkunakitti, Porntip (2005), "Cash Flows and Accruals Accounting in Predicting Future Cash Flows." unpublished Phd dissertation, University of Southern Cross.

Dechow, P.M. (1994).Accounting earnings and cash flows as measures of firm performance: the role of accounting accruals. Journal of Accounting and Economics, 18 (1), 3-42.

Dechow, P.M., Kothari, S.P. \& Watts, R.L. (1998).The relation between earnings and cash flows. Journal of Accounting and Economics, 25(2), 13-68.

Efayena,O.(2015). The role of accrual accounting basis in the prediction of future cash flows: The Nigerian evidence. Research Journal of Finance and Accounting, 6(4)

Farshadfar, S., Ng, C., \& Brimble, M. (2008). The relative ability of earnings and cash flow data in forecasting future cash flows. Pacific Accounting Review, 20(3): 251-268.

Financial Accounting Standards Board (FASB) (1978). Objectives of Financial Reporting by Business Enterprises. Statement of Financial Accounting Concepts No. 1 Stamford, CT:FASB.

Finger, C.A. (1994).The ability of earnings to predict future earnings and cash flows. Journal of Accounting Research, 32(2), 210-23.

Greenberg, R.R., Johnson, G.L. and Ramesh, K. (1986).Earnings versus cash flows as a predictor of future cash flow measures. Journal of Accounting, Auditing and Finance, 1,266-77.

Hair, J. E, Anderson, R. E., Tatham, R. L. \&Black, W. C. (1998). Multivariate Data analysis, USA: Prentice-Hall International Inc. p. 143.

Holthausen, R. W. \& Watts, R. L. ( 2001). The Relevance of the value-relevance literature for financial accounting standard setting, Journal of Accounting \& Economics, 31(3), 75.

Janatrostami, M. T. (1999). The Review of Role and Predictability Earnings in Predicting Earnings and Future Cash Flows of Investment in Listed Companies in Tehran Stock Exchange. Department of Management and Accounting, Shahid Beheshti University, Unpublished M. A., Dissertation.

Jemâa, O.B., Toukabri, M., \& Jilani, F. (2015).The examination of the ability of earnings and cash flow in predicting future cash flows: Application to the Tunisian context. Accounting and Finance Research,4(1)

Jemâa,O.B., Toukabri, M.,\& Jilani,F.(2015). Accruals and the prediction of future operating cash-flows: Evidence from Tunisian companies. International Journal of Accounting and 
Economics Studies,3(1)

Kelly, J. \& O'Connor, J. (1997).Is profit more important than cash flow?', Management Accounting, 75(6),28-9.

Klein, A., \& Marquardt, C. (2006). Fundamentals of accounting losses. The Accounting Review , 81 (1), 179-206.

Lee, T. A. (1993). Cash Flow Reporting: Recent History of an Accounting Practice. New Works in Accounting History, New York: Garland Pub.

Lind, D. A., William, G. M., \& Samuel, A. W. (2008). Statistical techniques in business and economics (13th ed.). New Delhi: Tata McGraw Hill.

Lorek, K.S. \&Willinger, G.L. 1996, 'A multivariate time-series prediction model for cash flow data. The Accounting Review,71(1),81-101.

Lawson, G.H. (1992).Studies in Cash Flow Accounting and Analysis, Garland Publishing, Inc.,New York and London.

Kim, M., \& Kross, W. (2005). The ability of earnings to predict future operating cash flows has been increasing- not decreasing. Journal of Accounting Research, 43(5): 753-780.

Klein, A., \& Marquardt, C. A. (2006).Fundamentals of Accounting Losses. The Accounting Review, 81(1), 179-206.

Lev, B., Li, S., \& Sougiannis, T. (2010). The Usefulness of Accounting Estimates for Predicting Cash Flows and Earnings. Review of Accounting Studies, 15: 779-807.

McBeth, K.H. (1993).Forecasting operating cash flow: Evidence on the comparative predictive abilities of net income and operating cash flow from actual cash flow data', The Mid-Atlantic Journal of Business,29(2),173-87.

Mooi,T.L.(2007).Predicting future cash flows: Does cash flow have incremental information over accruals earnings?.Malysian Accounting Review,6(2).

Neter, J. Wasserman, W. \& Kutner, M. (1985). Applied Linear Statistical Models, Homewood: Richard D. Irwin, p. 392.

Neill, J.D., Schaefer, T.F., Bahnson, P.R. \& Bradbury, M.E. (1991).The usefulness of cash flow data: a review and synthesis. Journal of Accounting Literature, 10,117-50.

Penham, S. H., \& Yehuda, N. (2009). The Pricing of earnings and cash flows and the affirmation of accrual accounting. Review of Accounting Studies, 14(4): 453-479.

Quirin, J. J., O'Bryan, D., Wilcox, W. E., \& Berry, K. T. (1999). Forecasting cash flow from operations: Additional evidence. Mid -Atlantic Journal of Business, 35, 135-142.

Sharma, A, Kumar, S, \& Singh, R (2012).Value Relevance of Financial Reporting and Its Impact on Stock Prices: Evidence from India. South Asian Journal of Management, 19(2), 60- 77.

Schaeffer, H.A. (2002).Cash flow: the lifeblood of a business', Controllers Update, no. 200(1),3.

Sloan, R. (1996). Do stock prices fully reflect information in accruals and cash flows about 


\section{Macrothink \\ International Journal of Accounting and Financial Reporting \\ ISSN 2162-3082 2015, Vol. 5, No. 2}

future earnings? The Accounting Review , 71 (3), 289-315.

Shubita,M.(2013).The Forecasting Ability of Earnings and Operating Cash Flow. Interdisciplinary Journal of Contemporary Research in Business,5(3).

Srinivasan, P. \& Narasimhan, M. S. (2010). An evaluation of value relevance of consolidated earnings and cash flow reporting in India. Proceedings of the 2nd International Conference on Corporate Governance, Retrieved January 21, 2013 from http://www.ssrn.com/vrresearchpapersindia/fulldownload-135 9187.htm

Takhtaei,N.,and Karim,H.(2013). Relative ability of earnings data and cash flow in predicting future cash flows. International Journal of Accounting and Financial Reporting,3(1).

Tharmir, A.B. (2011). Value relevance and predictive ability of financial statement information: the case of Saudi Arabia. PhD Thesis, University of Portsmouth, England.

Telmoudi, A. Noubbigh, H. \& Ziadi, J (2010).Forecasting of Operating Cash Flow: Case of the Tunisian Commercial Companies. International Journal of Business and Management, $5(10)$.

Vishnani, S., \& Shah, K. B. (2008). Value relevance of published financial statements with special emphasis on impact of cash flow reporting. International Research Journal of Finance and Economics, 17(3), 84-90.

Waldron, M. A., \& Jordan, C.E. (2010). The comparative predictive abilities of accrual earnings and cash flows in periods of economic turbulence; the case of the IT bubble. The Journal of Applied Business Research,26(1): 85-97

Wardhani and Almila (2013). The predictive power of earnings and cash flows (testing at the every stage of company's life cycle). The Indonesian Accounting Review, 3(1).

Zwaig, M.C. \& Pickett, M.M. (2001.) Early warning signs of a bankruptcy. Business Credit, $103,(1)-65$. 